University of Nebraska - Lincoln

DigitalCommons@University of Nebraska - Lincoln

INNOVATIVE REMOTE SENSING TECHNIQUES TO INCREASE NITROGEN USE EFFICIENCY OF CORN

Walter C. Bausch

USDA-ARS

Kenan Diker

University of Cukurova

Follow this and additional works at: https://digitalcommons.unl.edu/usdaarsfacpub

Part of the Agricultural Science Commons

Bausch, Walter C. and Diker, Kenan, "INNOVATIVE REMOTE SENSING TECHNIQUES TO INCREASE NITROGEN USE EFFICIENCY OF CORN" (2001). Publications from USDA-ARS / UNL Faculty. 519. https://digitalcommons.unl.edu/usdaarsfacpub/519

This Article is brought to you for free and open access by the U.S. Department of Agriculture: Agricultural Research Service, Lincoln, Nebraska at DigitalCommons@University of Nebraska - Lincoln. It has been accepted for inclusion in Publications from USDA-ARS / UNL Faculty by an authorized administrator of DigitalCommons@University of Nebraska - Lincoln. 


\title{
INNOVATIVE REMOTE SENSING TECHNIQUES TO INCREASE NITROGEN USE EFFICIENCY OF CORN
}

\author{
Walter C. Bausch ${ }^{1}$ and Kenan Diker ${ }^{2}$ \\ ${ }^{1}$ USDA-ARS Water Management Research Unit, \\ AERC-CSU Foothills, Ft. Collins, CO 80523 \\ ${ }^{2}$ Department of Agricultural Engineering, Faculty of \\ Agriculture, University of Cukurova, Adana/Turkey
}

\begin{abstract}
Nitrogen $(\mathrm{N})$ fertilizer recommendations made without adequate knowledge of the $\mathrm{N}$ supply capability of a soil can lead to inefficient use of N. Proper crediting of $\mathrm{N}$ from manure and legumes as well as mineralization of $\mathrm{N}$ from organic matter is difficult. Remote sensing techniques that use the crop to indicate its $\mathrm{N}$ status show considerable promise for improving $\mathrm{N}$ management. Objectives of this paper were twofold: 1) to compare the N Reflectance Index (NRI) calculated from ground-based radiometer measurements acquired over irrigated corn (Zea mays L.) at a nadir view $\left(0^{\circ}\right)$ and an oblique view $\left(75^{\circ}\right)$ with measured plant $\mathrm{N}$ and 2 ) to evaluate the NRI obtained from both view angles for correcting in-season $\mathrm{N}$ deficiencies in a commercial corn field. The NRI calculated from canopy reflectance was not representative of plant $\mathrm{N}$ at the sixth leaf growth stage (V6) for either view angle because of the soil background influence on canopy reflectance. However, the oblique view NRI was a good predictor of plant N at V9 and V12 as was
\end{abstract}


the nadir view NRI at V12. The nadir view NRI was not as sensitive as the oblique view NRI at the V9 growth stage because soil was still visible through the canopy. Consequently, the nadir view NRI provides a conservative estimate of plant $\mathrm{N}$ prior to complete canopy cover. Use of the nadir view NRI to detect in-season corn $\mathrm{N}$ deficiencies for the 1999 growing season reduced $\mathrm{N}$ application during the growing season by $39.2 \mathrm{~kg} \mathrm{~N} \mathrm{ha}^{-1}$ without reducing grain yield. If the oblique view NRI would have been used to assess the plant $\mathrm{N}$ status, the first fertigation would not have been recommended which would have saved additional $\mathrm{N}$.

\section{INTRODUCTION}

A survey of nutrient use in the US indicated that nitrogen $(\mathrm{N})$ fertilizer from commercial sources was applied to $97 \%$ of the area planted to corn (AREI Updates, 1996). Schepers et al. (1995) reported that 50 to $80 \%$ of the $\mathrm{N}$ fertilizer used on corn was applied prior to planting; however, this practice varies with location. Less than $20 \%$ of the total $\mathrm{N}$ uptake by corn occurs prior to the late side dress (eight mature leaves) application time (Schepers, et al., 1995). Consequently, considerable nitrate leaching can occur when all the $\mathrm{N}$ fertilizer is applied before or at planting due to excessive Spring rainfall or irrigation. Concerns related to nitrate contamination of ground and surface water supplies resulting from inefficient use of $\mathrm{N}$ fertilizer have precipitated research to increase $\mathrm{N}$ use efficiency beyond current best management practices.

Efficient nitrogen fertilizer management can be defined as managing $\mathrm{N}$ fertilizer so the crop uses as much of the applied nitrogen as possible each year (Ferguson et al., 1994). To accomplish this, producers must be aware of the various sources of $\mathrm{N}$ available to the crop other than fertilizer and how to minimize $\mathrm{N}$ loss. The total amount of $\mathrm{N}$ required must be determined from reasonable estimates of yield, residual soil nitrate-nitrogen, and soil organic matter followed by an evaluation of $\mathrm{N}$ credit from other sources such as irrigation water, legumes, and manure. Proper crediting of $\mathrm{N}$ from legumes and manure as well as mineralization of $\mathrm{N}$ from organic matter (which can provide substantial inorganic $\mathrm{N}$ to a crop) is difficult to predict. Rather than attempting to predict the N supply capability from these sources, it may be easier to allow the crop to indicate its $\mathrm{N}$ status (Ferguson et al., 1994; 1998) and respond accordingly.

Plant $\mathrm{N}$ can be estimated from tissue sampling, chlorophyll meter measurements (Piekielek and Fox, 1992; Schepers et al., 1992; Wood et al., 1992), and remote sensing (McMurtrey et al., 1994; Bausch and Duke, 1996; Blackmer et al., 1996; Stone et al., 1996). Tissue sampling for nitrogen availability is well documented and requires considerable effort for sample collection and processing. In 
addition, results are not immediately available. Blackmer and Schepers (1995) demonstrated use of the Minolta ${ }^{1}$ SPAD chlorophyll meter and the N Sufficiency Index (NSI), i.e., SPAD measurements for an area of interest normalized to SPAD measurements for a reference area that is not $\mathrm{N}$ deficient, as effective tools to schedule $\mathrm{N}$ fertigation for corn "as needed" by the crop. Data obtained with the SPAD chlorophyll meter is a point measurement on a single leaf from a single plant. Peterson et al. (1993) indicate that care must be taken during collection of these measurements because individual readings may vary up to $15 \%$ from plant to plant. Thus, many plants must be sampled to obtain a representative average value to adequately assess the plant $\mathrm{N}$ status for the particular sampling date. Remote sensing has the capability of sampling a plant community (a function of pixel size) rather than a single point on a single plant and of rapidly assessing the spatial variability in a field. Stone et al. (1996) developed a plant nitrogen spectral index (PNSI) for correcting in-season wheat $\mathrm{N}$ deficiencies from canopy radiance data measured in the red $(671 \pm 6 \mathrm{~nm})$ and near-infrared $(780 \pm 6 \mathrm{~nm})$ portions of the electromagnetic spectrum. The PNSI is the absolute value of the inverse of the normalized difference vegetation index (NDVI) which requires red and nearinfrared (NIR) spectral data. Variable $\mathrm{N}$ rate treated plots based on the PNSI resulted in a total $\mathrm{N}$ savings between 32 and $57 \mathrm{~kg} \mathrm{~N}$ ha $^{-1}$ when compared to fixed rate topdress $\mathrm{N}$ rate plots. Blackmer et al. (1996) presented spectroradiometer measured reflected radiation of corn at the dent growth stage [R5 (Ritchie et al., 1986)] which showed that canopy radiance near $550 \mathrm{~nm}$ and $710 \mathrm{~nm}$ was superior to canopy radiance near $450 \mathrm{~nm}$ or $650 \mathrm{~nm}$ for detecting $\mathrm{N}$ deficiencies. Their results also showed that the ratio of canopy radiance in the 550- to 600-nm interval to the 800- to $900-\mathrm{nm}$ interval provided sensitive detection of $\mathrm{N}$ stress. Based on results presented by McMurtrey et al. (1994) and others that have reported nutrient deficiency effects on leaf reflectance, Bausch and Duke (1996) developed a N Reflectance Index (NRI) to monitor plant $\mathrm{N}$ status of irrigated corn from green (520 to $600 \mathrm{~nm}$ ) and NIR (760 to $900 \mathrm{~nm}$ ) canopy reflectance. The NRI was defined as a ratio of the NIR/green for an area of interest to the NIR/green for a well $\mathrm{N}$-fertilized reference area. Comparison of the NRI and the NSI produced a near $1: 1$ relationship for corn growth stages between V11 and R4. Data plots of the NRI versus plant tissue total $\mathrm{N}$ concentration and the NSI versus plant tissue total $\mathrm{N}$ concentration produced very similar slopes and intercepts.

The NRI presented by Bausch and Duke (1996) was calculated from ground-based radiometer measurements acquired from a nadir view $\left(0^{\circ}\right)$ angle, i.e., perpendicular to the crop surface. Based on data presented by Bausch et al. (1996), comparisons between measured and estimated plant total $\mathrm{N}$ (all leaves)

1 Brand names are provided for the benefit of the reader; they do not imply endorsement by the authors or their employers (USDA-ARS or University of Cukurova). 
indicated that the NRI represented the N status in corn when the soil background was obscured by the crop canopy. Thus, a nadir viewing radiometer is useful when the corn canopy effectively obscures the soil surface which may occur by the V12 growth stage (12 mature leaves). Hergert et al. (1995) reported that rapid N uptake by corn begins about the tenth leaf stage (V10). Thus, remotely sensed data for $\mathrm{N}$ deficiency assessment in corn must adequately represent the plant $\mathrm{N}$ status prior to the V10 growth stage. The objective of this paper is twofold: 1) to compare the NRI calculated from ground-based radiometer measurements acquired at a nadir view $\left(0^{\circ}\right)$ angle and an oblique view $\left(75^{\circ}\right)$ angle to measured plant $\mathrm{N}$ and 2 ) to evaluate the NRI calculated from canopy reflectance data obtained from both view angles for correcting in-season corn $\mathrm{N}$ deficiencies in a commercial corn field.

\section{MATERIALS AND METHODS}

This experiment was conducted at Ft. Collins and Wiggins, CO. Research to investigate use of an oblique view angle to minimize soil background effects early in the growing season was conducted at the Agricultural Research, Development, and Education Center (ARDEC), Colorado State University, northeast of Ft. Collins. Data were collected during the 1995 and 1996 growing seasons on six nonreplicated plots that had $\mathrm{N}$ levels of $0,56,84,112,168$, and $224 \mathrm{~kg} \mathrm{~N} \mathrm{ha}^{-1}$. The zero treatment was residual $\mathrm{N}$ which was $18 \mathrm{~kg} \mathrm{~N} \mathrm{ha}^{-1}$ in 1995 and $22 \mathrm{~kg} \mathrm{~N}$ $\mathrm{ha}^{-1}$ in 1996 as determined from preseason soil sampling (0.6 m depth). Urea ammonium nitrate (UAN, $32 \% \mathrm{~N}$ ) was applied before planting to the other plots based on their residual $\mathrm{N}$ to produce the required $\mathrm{N}$ level. The $224 \mathrm{~kg} \mathrm{~N} \mathrm{ha}^{-1}$ treatment was used as a reference area. Plots were 30 rows $(0.76 \mathrm{~m}$ spacing) wide by $22 \mathrm{~m}$ long; plot width was halved in 1996 to accommodate two hybrids within the same N treatment. Pioneer hybrid 3790 (95-day maturity, planophyle canopy) was planted in 1995 and 1996; NC+ hybrid 1498 (94-day maturity, erectophyle canopy) was also planted in 1996. Corn was planted on May 12, 1995 [Day Of Year (DOY) 132] and May 2, 1996 (DOY 123) in north/south rows; sowing rate was approximately 84000 seeds ha ${ }^{-1}$. The plot area was furrow irrigated using surge technology. Soil in the plot area was classified as a Fort Collins loam (Fineloamy, mixed, mesic Ustollic Haplargids); however, soil texture analysis indicated the soil to be a clay loam.

Evaluation of the NRI to detect in-season $\mathrm{N}$ deficiencies in irrigated corn was conducted on a commercial farm northeast of Wiggins during the 1999 growing season. The field used in this study contained a sandy soil, had considerable topographic relief, and was center-pivot irrigated. A portion of the field was selected for the experiment as shown in figure 1 (shaded truncated wedge). The rotated three dimensional view of the topographic map depicts the elevation differences $(4.9 \mathrm{~m})$ that existed within the study area. The full wedge was 3.8 ha in 

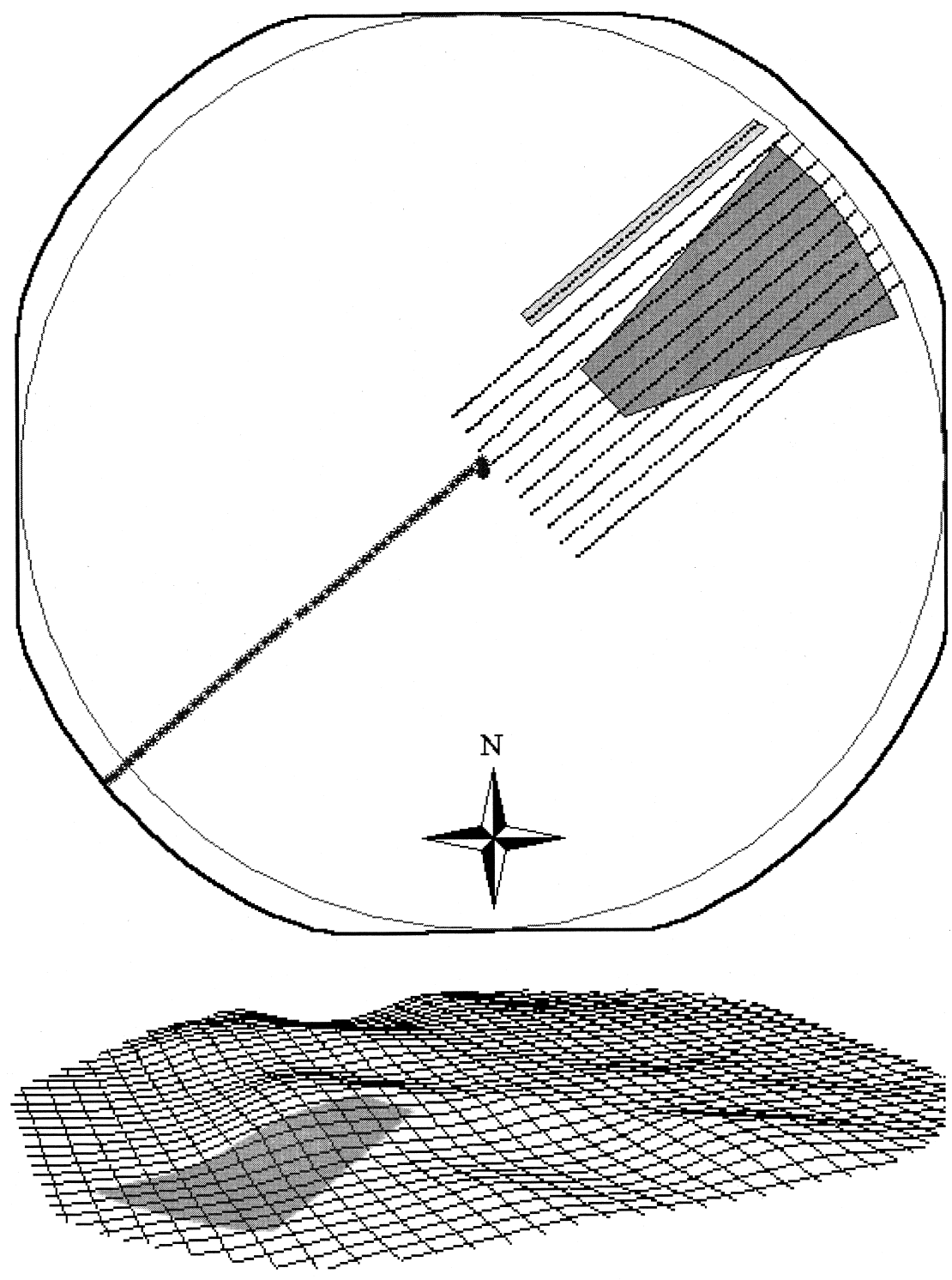

Figure 1. Study area within the commercial field. 
size and consisted of three soil types. The hill area was a Valentine fine sand (Mixed, mesic Typic Ustipsamments) which made up two-thirds of the area; the low area contained a Bijou loamy sand (Coarse-loamy, mixed, superactive, mesic Ustic Haplargids) and a Truckton coarse sandy loam (Coarse-loamy, mixed, superactive, mesic Aridic Argiustolls). The cooperating farmer applied $56 \mathrm{~kg} \mathrm{~N}$ $\mathrm{ha}^{-1}, 90 \mathrm{~kg} \mathrm{~K} \mathrm{ha}^{-1}$, and $11 \mathrm{~kg} \mathrm{Sha}^{-1}$ on 26 April (DOY 116); the field was ripped and disc harrowed the following day. Corn (Pioneer hybrid 35R58, erectophyle canopy) was planted on 7 May (DOY 127) at 84,700 seeds ha ${ }^{-1}$; a starter fertilizer solution consisting of $28 \mathrm{~kg} \mathrm{~N}^{-1}, 39 \mathrm{~kg} \mathrm{Pha}^{-1}, 6 \mathrm{~kg} \mathrm{~S}^{-1}$, and $1 \mathrm{~kg} \mathrm{Zn} \mathrm{ha}^{-1}$ was applied at planting. Row direction was $50^{\circ}$ from north. A reference area (shaded rectangle in figure 1) was established by applying $132 \mathrm{~kg} \mathrm{~N} \mathrm{ha}^{-1}$ to 16 rows on 24 June, DOY 175 (V7 growth stage). Timing of additional N (UAN) applied to the wedge during the growing season via fertigation was based on the $\mathrm{NRI}$; the amount of $\mathrm{N}$ applied was the farmer's decision. The farmer fertigated the remainder of the field (outside the wedge) at his discretion.

Plant measurements consisting of leaf area, SPAD, plant tissue samples, and canopy radiance were made at ARDEC. All measurements were made on the same day; cloud-free days were selected when possible. In 1995, these measurements were made on 10 July (V6), 25 July (V9), 1 Aug. (V12), 7 Aug. (V15), and 28 Aug. (R2); in 1996, measurement dates were 18 June (V5), 24 June (V6), 2 July (V7), 11 July (V9), 17 July (V12), 22 July (V14), 31 July (R1 for hybrid 3790 and V16 for hybrid 1498), 6 Aug. (VT for hybrid 1498), 13 Aug. (R2 for 3790 and R1 for 1498), and 3 Sept. (R4 for 3790 and R3 for 1498). Canopy radiance and SPAD were measured at Wiggins in 1999 on 25 June (V7), 1 July (V8), 8 July (V10), 14 July (V12), 21 July (V15), 26 July (VT/R1), 11 Aug (R2), 16 Aug (R3).

Leaf area was measured with a portable Li-Cor LI-3000A area meter to evaluate plant growth differences between $\mathrm{N}$ treatments. Ten plants selected at random within each treatment were measured, and the leaf area index (LAI) was calculated based on plant population.

SPAD chlorophyll meter measurements were taken using procedures outlined by Peterson et al. (1993). These measurements were made on 30 representative plants in each treatment; the average SPAD value (as calculated by the meter) was recorded. The most recently mature leaf (leaf collar exposed) was used at each measurement date until tasseling (VT); at that time and thereafter the ear leaf was measured. A modified SPAD meter with RS-232 output was interfaced with a backpack differential GPS receiver (Trimble Ag-132) and a StarLogger (Spectrum Technologies, Inc.) datalogger for spatial SPAD measurements at the commercial farm site.

Eight plants were removed from each treatment at ARDEC for $\mathrm{N}$ analysis. Plants were separated into leaves and stems; each component was a composite sample for each $\mathrm{N}$ treatment. Plant samples were oven dried at $65^{\circ} \mathrm{C}$ for $24 \mathrm{~h}$ and 
ground. Subsamples were weighed and placed in a LECO, model CHN-1000, analyzer; the analyzer used the Dumas method (Bremner and Mulvaney, 1982) which is a dry oxidation (combustion) technique. Analyzer output was expressed as total $\mathrm{N}(\%)$.

Corn canopy radiance and incoming irradiance were measured simultaneously with a boom-type data acquisition system similar to that described by Bausch et al. (1990). The boom was mounted on a high-clearance tractor for field access. This system consisted of two instrument platforms with Exotech 100BX four-band radiometers and a Campbell Scientific Inc. (CSI) datalogger (a CSI 21X was used in 1995 and 1996 while a CSI 23X was used in 1999) to sample and store radiometer sensor voltages as well as time of measurement. One instrument platform was attached to the boom; the other was mounted on the tractor's roll over protection system (ROPS). Both instrument platforms provided two-way leveling to keep the radiometers level. The down-looking radiometer (on boom) measured target radiance and was fitted with $15^{\circ}$ field of view (FOV) optics; it was fixed in its nadir position $\left(0^{\circ}\right.$ view angle), i.e., pointed perpendicular to the crop surface. The other radiometer (on tractor ROPS) looked upward to measure irradiance; its FOV was $180^{\circ}$. Height of the down-looking radiometer above ground was $10 \mathrm{~m}$; the viewed spot was circular with a diameter of $2.6 \mathrm{~m}$. A third Exotech four-band radiometer $\left(15^{\circ} \mathrm{FOV}\right)$ was positioned near the right side of the tractor on a vertical support; its view was perpendicular to the crop rows. The radiometer mounting bracket was fixed at a $15^{\circ}$ angle below the horizontal such that the radiometer measurement represented a $75^{\circ}$ view. This angle was selected to minimize the amount of soil viewed by the radiometer for crop canopy radiance measurements. With this radiometer positioned $1 \mathrm{~m}$ above the crop canopy, the viewed spot was an ellipse with dimensions of $5.2 \mathrm{~m}$ (major axis) and $1.2 \mathrm{~m}$ (minor axis). The center of the ellipse was within $0.4 \mathrm{~m}$ of the center of the circular spot viewed from the nadir-positioned radiometer. The $75^{\circ}$-view radiometer was adjusted to $1 \mathrm{~m}$ above the mean canopy height before each measurement session.

Radiant energy was measured in discrete wavebands in the blue, green, red, and near-infrared (450 to $520 \mathrm{~nm}, 520$ to $600 \mathrm{~nm}, 630$ to $690 \mathrm{~nm}$, and 760 to $900 \mathrm{~nm}$, respectively) which are similar to the Landsat Thematic Mapper wavebands. Measurements were taken around solar noon for the north/south row direction at the ARDEC site and around 2:15 PM MDT at the commercial farm site to ensure that the solar azimuth angle was approximately parallel to the crop rows. Data points were acquired and stored every $2 \mathrm{~s}$ when the datalogger was triggered to record data. Each data point consisted of canopy radiance from 25 to 35 plants (nadir view) depending on crop height and approximately 35 plants for the $75^{\circ}$ view. Position (longitude and latitude) of each data point was determined with real-time differential GPS equipment (Ashtech SCA-12). The differential correction from the base station receiver was transmitted to the rover receiver using FreeWave Technologies Inc. DGR-115H Wireless Data Transceivers. The 
rover GPS antenna was mounted on the instrument platform directly above the down-looking radiometer; accuracy of the instantaneous horizontal position was sub-meter.

Canopy reflectance was calculated for each waveband based on an intercalibration of the up-looking radiometer and the target-viewing radiometers with respect to a calibrated $\mathrm{BaSO}_{4}$ panel (Neale, 1987). The computer program that calculated canopy reflectance from measured radiometer voltages also associated the GPS position with canopy reflectance data. This data file was imported into ArcView for calculation of the NRI and to map its spatial variation if desired. Zonal statistics (mean, standard deviation, min, max) for areas of interest were calculated within ArcView. The N Reflectance Index (NRI) was calculated as a ratio of the NIR/green for each individual data point to the mean NIR/green from the reference area.

\section{RESULTS AND DISCUSSION}

\section{Effect of View Angle on the NRI}

Figure 2 shows relationships between leaf total $\mathrm{N}$ and the $\mathrm{N}$ Sufficiency Index (NSI), NRI-nadir view, and the NRI- $75^{\circ}$ view at the V6, V9, and V12 growth stages for combined 1995 and 1996 growing season data. LAI (excluding the two low $\mathrm{N}$ treatments) varied from 0.4 to 0.6 at V6, from 1.9 to 2.5 at $\mathrm{V} 9$, and from 2.8 to 3.3 at V12. Canopy ground cover (average value) determined from $35 \mathrm{~mm}$ slides was $28 \%, 66 \%$, and $85 \%$ at V6, V9, and V12, respectively. For this study, corn in its V12 growth stage was considered to be at effective cover based on general guidelines (LAI $=3$ and/or $75 \%$ ground cover) presented by Stegman et al. (1980).

Comparison of the NRI versus leaf total $\mathrm{N}$ relationships to the NSI versus leaf total $\mathrm{N}$ relationship gave an indication of how well the NRI calculated from the two radiometer view angles represented the plant $\mathrm{N}$ status at the particular growth stage. The assumption was that the NSI adequately represented plant $\mathrm{N}$ since SPAD measurements were directly made on the plant leaves. Table 1 lists linear regression parameters (slope, intercept, and coefficient of determination) for each relationship. At the V6 growth stage, the NRI calculated from canopy reflectance acquired from a nadir view or a $75^{\circ}$ view radiometer was not representative of plant $\mathrm{N}$ because of the soil background influence on canopy reflectance. However, the $75^{\circ}$ view NRI data points were clustered more tightly about the regression line than the nadir view NRI data which indicates that more plant and less soil was visible; this was more evident at the V9 and V12 growth stages. Also, the $75^{\circ}$ view NRI versus total $\mathrm{N}$ relationship at the V9 and V12 growth stages had regression slopes similar to the NSI-total N relationship. Based on the coefficient 

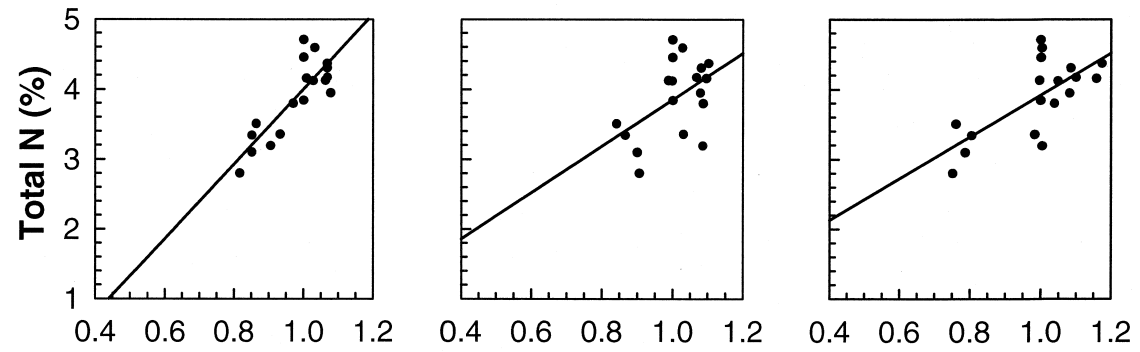

(a) V6 growth stage
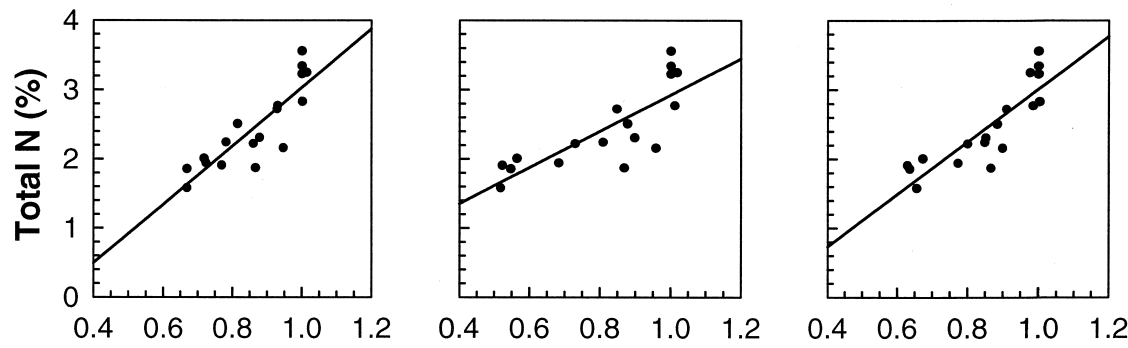

(b) V9 growth stage
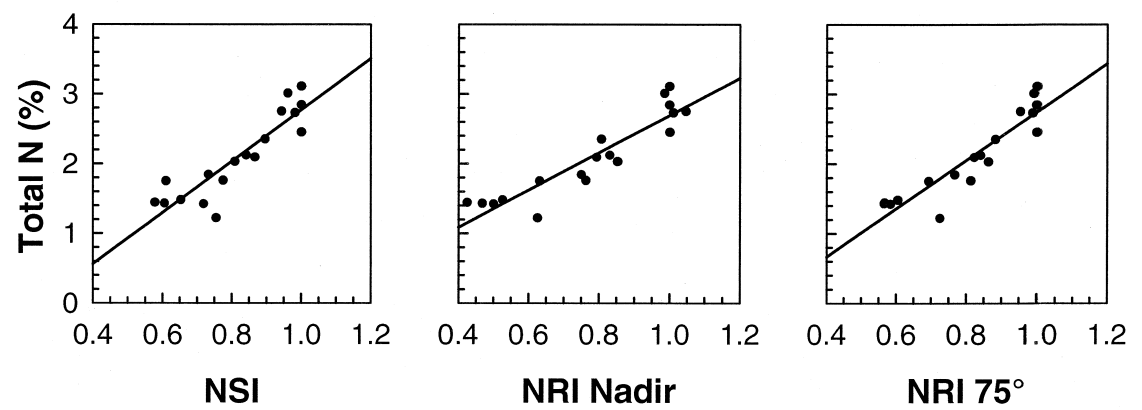

(c) V12 growth stage

Figure 2. Comparison of leaf total $\mathrm{N}$ with the NSI, the NRI-nadir view, and the NRI$75^{\circ}$ view at the V6, V9, and V12 corn growth stages. 
Table 1. Regression Parameters for the Relationships Between Leaf Total N and the NSI, the NRI-Nadir View, and the NRI-75 ${ }^{\circ}$ View at Various Corn Growth Stages

\begin{tabular}{|c|c|c|c|c|c|c|c|c|c|}
\hline \multirow{2}{*}{$\begin{array}{l}\text { Growth } \\
\text { Stage }\end{array}$} & \multicolumn{3}{|c|}{ NSI } & \multicolumn{3}{|c|}{ NRI-Nadir View } & \multicolumn{3}{|c|}{$\mathrm{NRI}-75^{\circ} \mathrm{View}$} \\
\hline & Slope & Intercept & $r^{2}$ & Slope & Intercept & $\mathrm{r}^{2}$ & Slope & Intercept & $r^{2}$ \\
\hline V6 & 5.36 & -1.35 & 0.71 & 3.33 & 0.52 & 0.24 & 2.99 & 0.93 & 0.49 \\
\hline V9 & 4.23 & -1.20 & 0.74 & 2.62 & 0.31 & 0.65 & 3.80 & -0.79 & 0.73 \\
\hline V12 & 3.68 & -0.91 & 0.80 & 2.68 & 0.02 & 0.84 & 3.46 & -0.72 & 0.84 \\
\hline
\end{tabular}

of determination, the $75^{\circ}$ view NRI was as good as the NSI for predicting plant N at the V9 and V12 growth stages. The nadir view NRI versus leaf total N relationship was as good as the $75^{\circ}$ view NRI and the NSI relationships at the V12 growth stage. The nadir view NRI also produced a good relationship with leaf total $\mathrm{N}$ at the V9 growth stage. However, the nadir view NRI is not as sensitive as the $75^{\circ}$ view NRI to plant $\mathrm{N}$ at these growth stages because soil is still visible through the canopy; as such, the nadir view NRI provides a conservative estimate of the plant $\mathrm{N}$ status prior to complete canopy cover.

Based on the suggestion by Hergert et al. (1995) that most of the nitrogen fertilizer needs to be applied prior to the tasseling stage to maximize the effect of applied N, NSI and NRI data were plotted against each other for the V9 through V16 growth stages to determine their relationship during rapid corn growth. Figure 3 shows the NSI versus the NRI calculated from nadir and $75^{\circ}$ view canopy reflectance data. Data from 1995 and 1996 (both canopy architectures) were included. The relationships had nearly identical coefficients of determination; however, the $75^{\circ}$ view NRI data had less scatter. Peterson et al. (1993) indicated that a NSI value less than 0.95 represented an $\mathrm{N}$ deficiency that should be corrected to minimize yield reduction; using this threshold, the NRI calculated from either relationship (NSI vs. nadir view NRI or NSI vs. $75^{\circ}$ view NRI) would also be 0.95. This NRI threshold was identical to that presented by Bausch and Duke (1996) for the V11 through R4 growth stages of corn. Therefore, a NRI less than 0.95 represents an $\mathrm{N}$ deficiency that needs correcting by applying additional $\mathrm{N}$. Temporal plots of the NRI for the 1996 growing season (V6 to R4) are presented in figures 4 and 5 for the 84, 112, and $168 \mathrm{~kg} \mathrm{~N} \mathrm{ha}^{-1} \mathrm{~N}$ levels. Figure 4 shows the NRI calculated from the nadir view radiometer data for the (a) planophyle and (b) erectophyle canopy architectures while figure 5 shows the NRI calculated from the $75^{\circ}$ view radiometer data. These plots show that the 84 and $112 \mathrm{~kg} \mathrm{~N} \mathrm{ha}^{-1}$ treatments became $\mathrm{N}$ deficient somewhere between the V7 (DOY 183) and the V9 (DOY 193) growth stage whereas the $168 \mathrm{~kg} \mathrm{~N}^{-1}$ treatment maintained an adequate $\mathrm{N}$ status. NRI data for the 1995 growing season also showed $\mathrm{N}$ deficiencies for the 84 and $112 \mathrm{~kg} \mathrm{~N} \mathrm{ha}^{-1}$ treatments at the V9 growth stage. At tasseling 



Figure 3. Relationships between the NSI and the NRI calculated farom nadir view and $75^{\circ}$ view radiometer data collected during the 1995 and 1996 growing seasons for the V9 through V16 corn growth stages. Data from 1996 contains both canopy architectures. 



Figure 4. Temporal plot of the NRI calculated from nadir view radiometer data for three $\mathrm{N}$ levels during the 1996 growing season (V6 to R4 growth stages) for the a) planophyle and b) erectophyle corn canopies. 

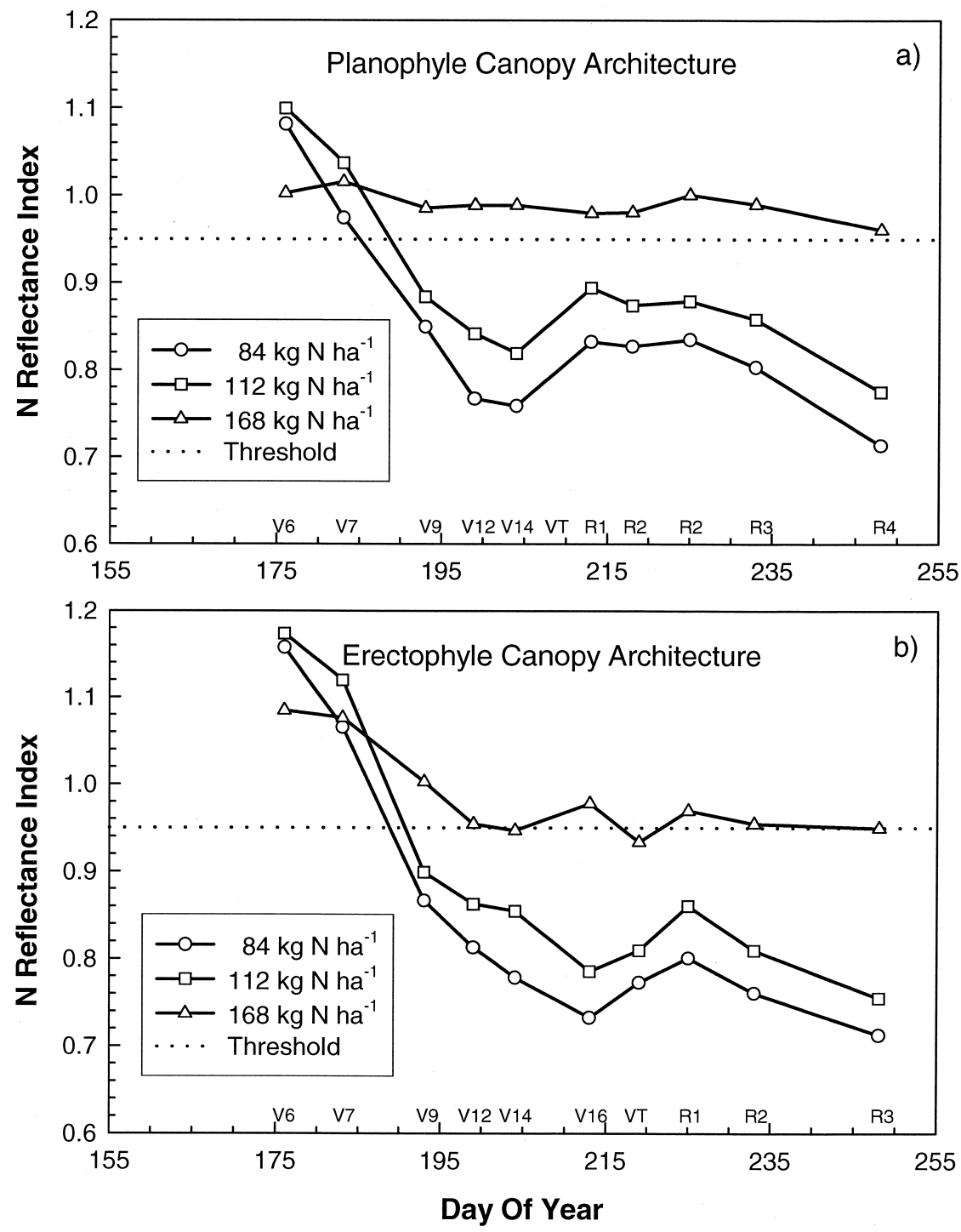

Figure 5. Temporal plot of the NRI calculated from $75^{\circ}$ view radiometer data for three $\mathrm{N}$ levels during the 1996 growing season (V6 to R4 growth stages) for the a) planophyle and b) erectophyle corn canopies. 
(DOY 208 for planophyle and DOY 218 for erectophyle) and thereafter, the NRI calculated from $75^{\circ}$ view radiometer data (Fig. 5) increased whereas the NRI calculated from nadir view data (Fig. 4) had minimal or no increase in value. Emergence of the tassel has a dramatic effect on canopy reflectance calculated from an oblique view radiometer due to its lighter color and possibly due to pollen grains on the corn leaves.

\section{Evaluation of the NRI}

Canopy reflectance was acquired at the commercial farm site starting on 25 June (DOY 176) at the V7 growth stage and at least once a week thereafter until the corn tasseled. By this time three fertigations ( $28 \mathrm{~kg} \mathrm{~N} \mathrm{ha}^{-1}$ each) had been applied to the field excluding the wedge. Mean values for the NRI and NSI within the wedge area as well as corn growth stage are presented in Table 2 at each data measurement session. On DOY 176, the nadir view NRI indicated an N deficiency; the $75^{\circ}$ view NRI did not. Since this measurement was relatively early in the growing season, the nadir view radiometer was still "seeing" considerable soil whereas the $75^{\circ}$ view radiometer saw mostly plant material. Consequently, no fertigation was recommended. Figure 6 shows the spatial variation of the NRI calculated from canopy reflectance data acquired on DOY 182 from the (a) nadir view and (b) $75^{\circ}$ view as well as (c) the NSI calculated from SPAD data. Ten transects as shown in figure 1 were used for data collection. The transect (GPS position of radiometer data) marked the center of the radiometer's field-of-view. SPAD data were collected within three rows of each transect. Radiometer data were acquired in approximately $0.5 \mathrm{hr}$ while spatial SPAD data collection took around $1.5 \mathrm{hr}$. As depicted in figure 6a, the nadir view NRI showed the sand hill

Table 2. Average Values of the NRI and the NSI Within the Wedge Area at the Commercial Farm Site and the Corn Growth Stage When Data Were Collected

\begin{tabular}{|c|c|c|c|c|}
\hline \multirow[b]{2}{*}{ DOY } & \multicolumn{2}{|c|}{ NRI } & \multirow[b]{2}{*}{ NSI } & \multirow{2}{*}{$\begin{array}{c}\text { Growth } \\
\text { Stage }\end{array}$} \\
\hline & Nadir View & $75^{\circ}$ View & & \\
\hline 176 & 0.94 & 0.96 & Not Available & V7 \\
\hline 182 & 0.95 & 1.07 & 0.97 & V8 \\
\hline 189 & 0.86 & 0.99 & 0.91 & V10 \\
\hline 195 & 0.91 (estimated) & 0.96 & 0.92 & V12 \\
\hline 202 & 0.91 & 0.92 & 0.91 & V15 \\
\hline 207 & 0.94 & 0.97 & 0.93 & $\mathrm{VT} / \mathrm{R} 1$ \\
\hline 223 & 1.02 & 1.01 & 0.99 & $\mathrm{R} 2$ \\
\hline 228 & 0.98 & 1.00 & Not Available & $\mathrm{R} 3$ \\
\hline
\end{tabular}



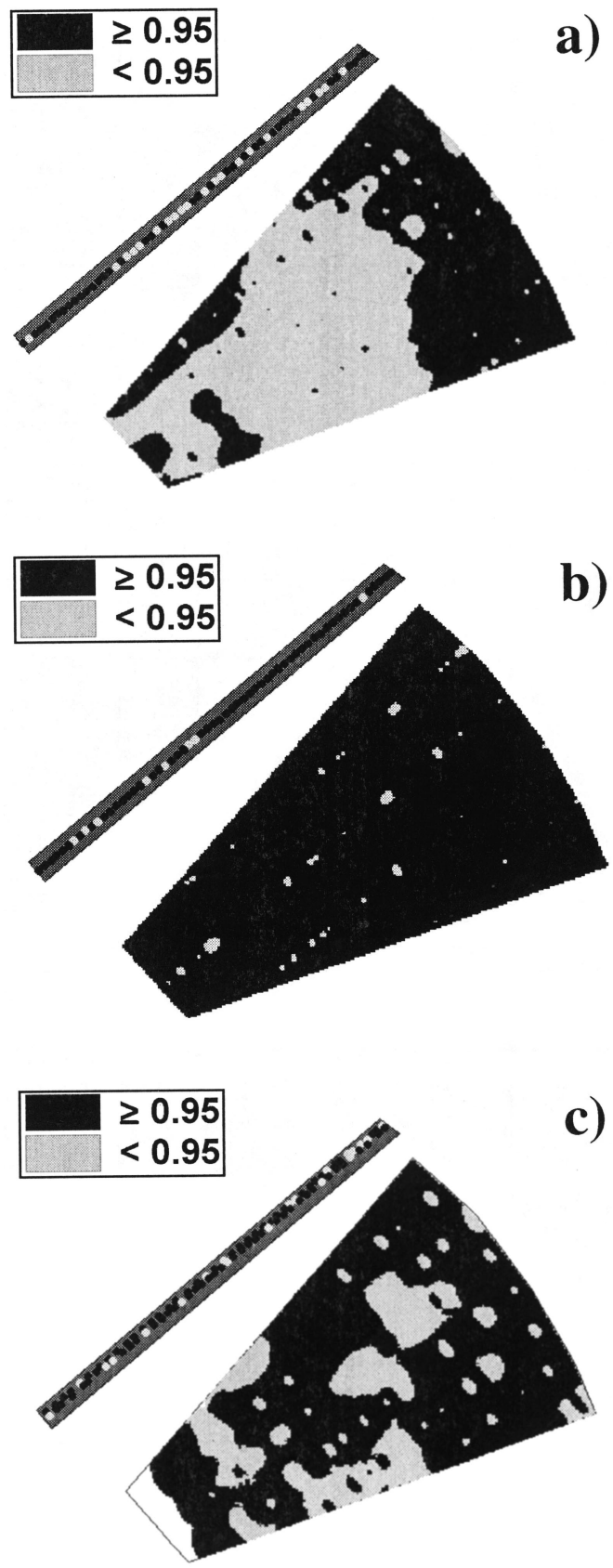

Figure 6. Spatial variation of the NRI calculated from a) nadir view and b) $75^{\circ}$ view radiometer data and c) the NSI calculated from SPAD data on DOY 182. 
area within the wedge as being $\mathrm{N}$ deficient. This was probably more related to the soil background influence on canopy reflectance than $\mathrm{N}$ status of the plant because the $75^{\circ}$ view NRI (Fig. 6b) showed only small $\mathrm{N}$ deficient spots. The NSI (Fig. 6c) showed isolated $\mathrm{N}$ deficient areas which were not as large as the area indicated by the nadir view NRI. Since this was a commercial farm site with a goal to be economically viable, the nadir view NRI was selected for recommending fertigation because less risk of reducing marketable yield was involved. The nadir view NRI had a mean value of 0.95 (Table 2), however, a significant area within the wedge showed as $\mathrm{N}$ deficient. Thus, fertigation of the wedge was recommended. An irrigation had started on DOY 182 and the cooperating farmer fertigated the wedge with $13.4 \mathrm{~kg} \mathrm{~N} \mathrm{ha}^{-1}$ as the sprinkler passed over the area.

Nadir view NRI values calculated from data collected on DOY 189, 195, and 202 indicated that the wedge needed fertigating on each of these days (Table 2). For DOY 195, the nadir view NRI was estimated from the mean NSI calculated from SPAD data by utilizing the relationship presented in figure 3 . The leveling mechanism for the nadir view radiometer platform malfunctioned that day; consequently, the radiometer's view was not 0. Data acquired on DOY 207 showed a response (NRI changed from 0.91 to 0.94 ) to the fertigation that was recommended on DOY 202. Unfortunately, the wedge did not get fertigated until DOY 204; therefore, additional $\mathrm{N}$ was not applied because the plants were probably still responding to the $\mathrm{N}$ application. Due to prolonged cloudy conditions, data were not acquired again until DOY 223. Data for that day and the next acquisition (DOY 228) showed that corn $\mathrm{N}$ deficiencies were corrected by the fertigation on DOY 204.

$\mathrm{N}$ amounts applied via fertigation during the growing season to the field and the wedge (in addition to preplant and starter fertilizer) are given in Table 3. Ad-

Table 3. Additional N Amounts Applied During the Growing Season via Fertigation to the Field and the Wedge at the Commercial Farm Site

\begin{tabular}{lccc}
\hline Date & DOY & $\begin{array}{c}\text { Field } \\
\left(\mathrm{kg} \mathrm{N} \mathrm{ha}^{-1}\right)\end{array}$ & $\begin{array}{c}\text { Wedge } \\
\left(\mathrm{kg} \mathrm{N} \mathrm{ha}^{-1}\right)\end{array}$ \\
\hline June 12 & 163 & 28.0 & 0 \\
June 14 & 165 & 28.0 & 0 \\
June 22 & 173 & 28.0 & 0 \\
July 1 & 182 & 0 & 13.4 \\
July 5 & 186 & 13.4 & 0 \\
July 8 & 189 & 13.4 & 13.4 \\
July 14 & 195 & 33.6 & 33.6 \\
July 23 & 204 & 0 & 44.8 \\
\hline
\end{tabular}


Table 4. Estimated N Requirement for the Wedge Area at the Commercial Farm Site Based on the Nadir View NRI

\begin{tabular}{lc}
\hline DOY & $\begin{array}{c}\text { Estimated N Requirement } \\
\left(\mathrm{kg} \mathrm{N} \mathrm{ha}^{-1}\right)\end{array}$ \\
\hline 182 & 16.2 \\
189 & 24.6 \\
195 & 17.7 \\
202 & 5.3 \\
207 & 0 \\
\hline
\end{tabular}

ditional $\mathrm{N}$ applied to the wedge was $105.2 \mathrm{~kg} \mathrm{~N}$ ha $^{-1}$ whereas the remainder of the field received $144.4 \mathrm{~kg} \mathrm{~N}^{-1}$. Mean grain yield (yield monitor data) was $13458 \mathrm{~kg} \mathrm{ha}^{-1}$ in the wedge and $12893 \mathrm{~kg} \mathrm{ha}^{-1}$ for the remainder of the field; standard deviation of yield in the two areas was 1475 and $1663 \mathrm{~kg} \mathrm{ha}^{-1}$, respectively. Although the wedge had a $4.4 \%$ increase in mean yield with less nitrogen (39.2 $\mathrm{kg} \mathrm{N} \mathrm{ha}^{-1}$ ) applied, one can only conclude that yield was not reduced due to the large standard deviations. In 1998, corn yield for the same two areas was 12736 and $12855 \mathrm{~kg} \mathrm{ha}^{-1}$ with standard deviations of 1927 and $2053 \mathrm{~kg} \mathrm{ha}^{-1}$. Mean grain yield within the wedge area was slightly less.

Utilization of the $75^{\circ}$ view NRI to recommend fertigation would have saved additional N. From data presented in Table 2 and shown by figure $6 \mathrm{~b}$, fertigation would not have been recommended on DOY 182. The fertigation on DOY 189 could have possibly been skipped also; however, that is purely speculative since $13.4 \mathrm{~kg} \mathrm{~N} \mathrm{ha}^{-1}$ was applied on DOY 182.

The ultimate goal for increasing nitrogen use efficiency via remotely sensed data is not only to detect $\mathrm{N}$ deficiencies, but also to estimate the amount of $\mathrm{N}$ that should be applied when an $\mathrm{N}$ deficiency is detected instead of guessing at the application as was done in this study. Diker (1998) developed an empirical approach for estimating the available soil $\mathrm{N}$ status as well as the $\mathrm{N}$ fertilizer required by using plant $\mathrm{N}$ as an indicator. Relationships between inorganic soil $\mathrm{N}\left(\mathrm{NO}_{3}+\right.$ $\mathrm{NH}_{4}$ ) and plant $\mathrm{N}$ as well as plant $\mathrm{N}$ and the NRI were developed at several corn growth stages from the ARDEC small plot $\mathrm{N}$ fertilizer level studies. The $168 \mathrm{~kg}$ $\mathrm{N}$ ha ${ }^{-1} \mathrm{~N}$ level was considered to be optimal soil $\mathrm{N}$ to support plant growth because plant $\mathrm{N}$ deficiencies did not develop (Figs. 4 and 5). In addition, grain yield between the 168 and $224 \mathrm{~kg} \mathrm{~N}^{-1} \mathrm{~N}$ levels were not significantly different. To obtain the suggested $\mathrm{N}$ amount to apply, an estimate of available inorganic soil $\mathrm{N}$ obtained from estimated plant $\mathrm{N}$ was subtracted from the optimal inorganic soil $\mathrm{N}$ at the particular growth stage. Optimal inorganic soil N levels at the V9, V12, $\mathrm{V} 15$, and R1 growth stages were $127,115,101$, and $90 \mathrm{~kg} \mathrm{~N} \mathrm{ha}^{-1}$. 
Relationships presented by Diker and Bausch (1998) were used to estimate the $\mathrm{N}$ fertilizer amount for the commercial farm site study. Table 4 gives these estimates based on the nadir view NRI. For DOY 182 and 189, the soil N equation developed for the V9 growth stage was used; the respective soil N equations (V12, V15, and R1) were used for DOY 195, 202, and 207. The N application estimate on DOY 182 was similar to that applied while the estimate on DOY $189(24.6 \mathrm{~kg}$ $\mathrm{N} \mathrm{ha}^{-1}$ ) was probably more realistic for an application than the $13.4 \mathrm{~kg} \mathrm{~N} \mathrm{ha}^{-1}$ that was applied. However, estimates for DOY 195 and 202 are obviously low. This is because the optimal inorganic soil $\mathrm{N}$ at specific growth stages is probably somewhat greater for the sandy soils at the commercial farm site than for the heavier textured soil at the ARDEC site which provides less chance for leaching when using best water management practices. The $\mathrm{N}$ application estimate for DOY 207 was $0 \mathrm{~kg} \mathrm{~N}$ ha $^{-1}$ (actually -0.2) which indicated that sufficient soil $\mathrm{N}$ was available at that growth stage.

\section{CONCLUSIONS}

The N Reflectance Index (NRI) calculated from ground-based canopy reflectance data acquired from the nadir view and the $75^{\circ}$ view at the V6 growth stage of corn was not representative of plant $\mathrm{N}$ because of the soil background influence on canopy reflectance. The $75^{\circ}$ view NRI was a good predictor of plant $\mathrm{N}$ at the V9 and V12 growth stages while the nadir view NRI was a good predictor at the V12 growth stage. The nadir view NRI also produced a good relationship with leaf total $\mathrm{N}$ at V9, but it is not as sensitive as the $75^{\circ}$ view NRI because soil is visible through the canopy. Consequently, the nadir view NRI provides a conservative estimate of the plant $\mathrm{N}$ status of corn prior to complete canopy cover.

Relationships developed between the NRI (both views) and the NSI from data representing the V9 through V16 corn growth stages had nearly identical coefficients of determination. However, the $75^{\circ}$ view NRI data had less scatter. Based on these relationships and the accepted NSI threshold of 0.95 to indicate an $\mathrm{N}$ deficiency, a NRI less than 0.95 also indicates an $\mathrm{N}$ deficiency that needs correcting by applying additional $\mathrm{N}$.

Evaluation of the NRI to correct corn N deficiencies during the 1999 growing season resulted in saving $39.2 \mathrm{~kg} \mathrm{~N}^{-1}$ without decreasing grain yield. This was accomplished using the nadir view NRI; use of the $75^{\circ} \mathrm{NRI}$ could have saved additional $\mathrm{N}$ by skipping the first fertigation.

\section{REFERENCES}

AREI Updates. 1996. 1995 nutrient use and practices on major field crops. USDA Economic Research Service, Natural Resources and Environment Division. No. 2, Washington, DC. 
Bausch, W.C., D.M. Lund, and M.C. Blue. 1990. Robotic data acquisition of directional reflectance factors. Remote Sens. Environ. 46(2):213-222.

Bausch, W.C. and H.R. Duke. 1996. Remote sensing of plant nitrogen status in corn. Transactions of the ASAE. 39(5):1869-1875.

Bausch, W.C., H.R. Duke, and C.J. Iremonger. 1996. Assessment of plant nitrogen in irrigated corn. pp. 23-32. In: P.C. Robert, R.H. Rust and W.E. Larson (eds.), Precision Agriculture, Proceedings of the 3rd International Conference. American Society of Agronomy/Crop Science Society of America/ Soil Science Society of America, Madison, WI.

Blackmer, T.M. and J.S. Schepers. 1995. Use of a chlorophyll meter to monitor nitrogen status and schedule fertigation for corn. J. Prod. Agric. 8(1): $56-60$.

Blackmer, T.M., J.S. Schepers, G.E. Varvel, and E.A. Walter-Shea. 1996. Nitrogen deficiency detection using reflected shortwave radiation from irrigated corn canopies. Agron. J. 88(1): 1-5.

Bremner, J.M. and G.S. Mulvaney. 1982. Nitrogen-total. pp. 595-624. In: A.L. Page, R.H. Miller, and D.R. Keeney (eds.), Methods of Soil Analysis, Part 2-Chemical and Microbiological Properties, 2nd Ed. Agron. No. 9. American Society of Agronomy, Madison, WI.

Diker, K. 1998. Use of geographic information management systems (GIMS) for nitrogen management. Ph.D. Dissertation, Colorado State Univ., Ft. Collins, CO. $141 \mathrm{pp}$.

Diker, K. and W.C. Bausch. 1998. Mapping in-season soil nitrogen variability assessed through remote sensing. pp. 1445-1455. In: P.C. Robert, R.H. Rust and W.E. Larson (eds.), Precision Agriculture, Proceedings of the 4th International Conference. American Society of Agronomy/Crop Science Society of America/Soil Science Society of America, Madison, WI.

Ferguson, R.B., E.J. Penas, C.A. Shapiro, and G.W. Hergert. 1994. Fertilizer nitrogen best management practices. NebGuide G94-1178-A. Cooperative Extension, Institute of Agriculture and Natural Resources, Univ. of NebraskaLincoln.

Ferguson, R.B, G.W. Hergert, J.S. Schepers, and C.A. Crawford. 1998. Sitespecific nitrogen management of irrigated corn. pp. 733-743. In: P.C. Robert, R.H. Rust and W.E. Larson (eds.), Precision Agriculture, Proceedings of the 4th International Conference. American Society of Agronomy/Crop Science Society of America/Soil Science Society of America, Madison, WI.

Hergert, G.W., R.B. Ferguson, and C.A. Shapiro. 1995. Fertilizer suggestions for corn. NebGuide G74-174-A. Cooperative Extension, Institute of Agriculture and Natural Resources, Univ. of Nebraska-Lincoln.

McMurtrey III, J.E., E.W. Chappelle, M.S. Kim, J.J. Meisinger, and L.A. Corp. 1994. Distinguishing nitrogen fertilization levels in field corn (Zea mays L.) with actively induced fluorescense and passive reflectance measurements. Remote Sens. Environ. 47(1):36-44. 
Neale, C.M.U. 1987. Development of reflectance based crop coefficients for corn. Ph.D. Dissertation, Colorado State Univ., Ft. Collins, CO. 170 pp.

Peterson, T.A., T.M. Blackmer, D.D. Francis, and J.S. Schepers. 1993. Using a chlorophyll meter to improve N management. NebGuide G93-1171-A. Cooperative Extension, Institute of Agriculture and Natural Resources, Univ. of Nebraska-Lincoln.

Piekielek, W.P. and R.H. Fox. 1992. Use of a chlorophyll meter to predict sidedress nitrogen requirements for maize. Agron. J. 84(1):59-65.

Ritchie, S.W., J.J. Hanaway, and G.O. Benson. 1986. How a corn plant develops. Special Report No. 48. Iowa State Univ. of Science and Technology, Coop. Ext. Serv. Ames, IA. 21 pp.

Schepers, J.S., D.D. Francis, M. Vigil, and F.E. Below. 1992. Comparison of corn leaf nitrogen concentration and chlorophyll meter readings. Commun. Soil Sci. Plant Anal. 23(17-20):2173-2187.

Schepers, J.S., D.D. Francis, and J.F. Power. 1995. Tissue analysis to improve nitrogen management practices. Clean Water-Clean Environment-21st Century. Vol II: Nutrients. pp. 195-198. American Society of Agricultural Engineers, St. Joseph, MI.

Stegman, E.C., J.T. Musick, and J.I. Stewart. 1980. Irrigation water management. pp. 763-816. In: M.E. Jensen (ed.), Design and Operation of Farm Irrigation Systems. American Society of Agricultural Engineers, St. Joseph, MI.

Stone, M.L., J.B. Solie, W.R. Raun, R.W. Whitney, S.L. Taylor, and J.D. Ringer. 1996. Use of spectral radiance for correcting in-season fertilizer nitrogen deficiencies in winter wheat. Transactions of the ASAE. 39(5): 1623-1631.

Wood, C.W., D.W. Reeves, R.R. Duffield, and K.L. Edmisten. 1992. Field chlorophyll measurements for evaluation of corn nitrogen status. J. Plant Nutrition. 15(4): 487-500. 